\title{
FLAVONOIDS AND STILBENES FROM ARMAND PINE
}

\author{
Jim-Min Fang, Wen-ChiUng Su and Yu-Shia Cheng* \\ Department of Chemistry, National Taiwan University, Taipe1, 10764, Taiwan, Repubhe of China
}

(Recelved 20 October 1987)

Key Word Index-Pinus armandu, Pinaceae, heartwood, flavonoids, stilbenes, chemotaxonomy.

\begin{abstract}
Seven flavonoids and seven stilbenes were isolated from the heartwood of Pinus armandil Fr. var. mastersiana Hay Among them, trans-3,5-dimethoxystilbene oxide is a new compound and 3-acetyloxy-5,7dihydroxyflavanone is the first report of its occurrence in nature. Comparison of the flavonord and stilbene components in $P$ armand $l, P$. morrisonicola Hay, and $P$. parvfflora Sieb et Zucc supports the chemotaxonomy of three spectes.
\end{abstract}

\section{INTRODUCTION}

Pinus armand $\iota$ Franchet var mastersiana Hayata. The armand pine, is an economically important conifer indigenous to the southwest region of China. Pinus arman$d n$ is morphologically as the Ta1wan endemic P. morrisonicola Hay. and Japanese white pine, Pinus parviflora Sieb. et Zucc [1]. We have recently shown that the flavonoid constitution of the heartwood of $P$. morrisonicola is different from that of $P$. parviflora [2]. A prelıminary paper chromatographic study of chemical constituents of $P$ armandii has been reported [3]. We here describe a detalled investigation of the flavonoids and stilbenes of the heartwood of $P$ armandll.

\section{RESULTS AND DISCUSSION}

The heartwood of $P$. armandi, collected in the Central Range of Tarwan [3], was exhaustively extracted with acetone. The concentrated extract was separated by chromatography to give seven flavonoids $(1-7)$ and seven stilbenes (8-14). Compounds 1-7 were identified as chrysin (1) [4], tectocrysin (2) [4], apigenin (3) [5, 6], pinocembrin (4) $[7,8]$, pinostrobin (5) $[7,9]$, pinobanksin (6) [10] and pinobanksin 3-acetate (7) [11] from their physical and spectroscopic properties (mp, [x], IR, MS, UV, and ${ }^{1} \mathrm{H}$ NMR). Compound (7), $[x]_{0}^{25}+42^{\circ}$, is the first report of its occurrence in nature while the synthetic sample (the stereochemistry not defined) has been used as an ant-inflammatory agent [11]. Compound 7 should have the trans configuration as that of pinobanksin by evidence of a large coupling constant $J_{2,3}$ of $12 \mathrm{~Hz}$. Since $P$ armand $u$ contains both flavones and flavanones, it belongs to the subgenus Haploxylon [12] The flavonoids of $P$ armand $l, P$. morrisonicola [2] and $P$. parviflora [13] are listed in Table 1 This comparison supports the chemotaxonomic basis of three spectes.

Two major stilbene compounds (8), $\mathrm{mp} 122-123^{\circ}$, and (9), $\operatorname{mp} 55-56^{\circ}$, were recognised as mono- and dimethyl ethers of trans-pinosylvin [14,15] as supported by their compatible spectral data (IR, MS, UV, ${ }^{1} \mathrm{H}$ and ${ }^{13} \mathrm{C}$ NMR) A $c t s$ isomer (10), three dihydro derivatives (11-13) and an oxide (14) were also isolated. The struc- tures $(10-14)$ were determined by spectroscopic analysis and chemical correlation as follows. The cis configuration of compound (10) was inferred by a relatively small coupling constant of $12 \mathrm{~Hz}$ between two vinyl protons [15]. Hydrogenation (Pd/C, EtOAc, $25^{\circ}, 4 \mathrm{hr}$ ) of stilbene (8) afforded a dibenzyl (11) [13]. Similarly, either stilbene (9) or the cis isomer (10) absorbed one equivelent of $\mathrm{H}_{2}$ to give compound (13). Treatment of (9) with $m$-chloroperbenzoic acid $\left(\mathrm{CH}_{2} \mathrm{Cl}_{2}, 25^{\circ}, 2 \mathrm{hr}\right)$ produced the oxide (14) and trans-2-hydroxy-3,5-dimethoxystılbene The new compound of oxide (14) was also found in the acetone extract of $P$ morrisonicola [16] However, whether the oxide (14) is a natural product or artifact remains uncertain Comparison of the stilbene constitution in $P$. armandi, $P$ morrisonicola and $P$. parviflora also indicates the species difference (Table 2). While flavonoids (1, 2 and 6) are major components in the acetone extract of heartwood of P. morrisonicola, the stilbenes $(8,9$ and 12$)$ are richly present in $P$. armandu

\section{EXPERIMENTAL}

Plant material The heartwood of Pinus armandı $\mathrm{Fr}$ var mastersiana Hay was collected in Gu-Kuang County, Taichung, in August 1984 A voucher specimen, identıfied by Dr Ta-Wel $\mathrm{Hu}$, has been deposited in the herbarium of the Tawan Forestry Institute The heartwood was sliced, arr-dried $(12 \mathrm{~kg})$ and extracted $\times 4$ with $\mathrm{Me}_{2} \mathrm{CO}$ The combined extracts $(390 \mathrm{~g})$ werc subjected to $\mathrm{CC}$ on $350 \mathrm{~g}$ of $\mathrm{StO}_{2}$ by elution with the gradients of hexane, EtOAc and $\mathrm{Me}_{2} \mathrm{CO}$ The components of each fraction were analysed by TLC, and the appropriate fractions were combined for further purification, by HPLC or by recrystallisation, to give flavonoids 1-7 (41 g) and stilbenes 8-14 (162 g)

3=Acetyloxy-5,7-dihydroxyflavanone (7) Colourless crystals, $\mathrm{mp} 173-175^{\circ},[\alpha]_{\mathrm{D}}^{25}+42^{\mathrm{c}}(\mathrm{MeOH}, c 1.7) \mathrm{MS} \mathrm{m} / z$ (rel int ) 314 $\left[\mathrm{M}^{+}\right]$(28), $272(11), 255$ (13), 254 (62), 243 (12), 208 (7), 195 (6), $166(21), 153(100), 152(23), 124(9), 120(60), 118(27), 103(4), 91$ (32) IR $v^{\mathrm{KBr}} \mathrm{cm}^{-1} 3420,1750,1630 \lambda_{\max }^{\mathrm{MeOH}} \mathrm{nm}(\varepsilon): 328(4300), 290$ $(17000), 223(16000), 209(25500)$, in the presence of $\mathrm{AlCl}_{3}, 378(2$ $860), 314(21000), 215(24000), 205(26000)$, in the presence of $\mathrm{AlCl}_{3}-\mathrm{HCl}, 380$ (3 570), 314 (23 000), 215 (23 600), 205 (26 000) ${ }^{1} \mathrm{H}$ NMR $\left(\mathrm{CDCl}_{3}, 300 \mathrm{MHz}\right) \delta 2.00(3 \mathrm{H}, s), 530(1 \mathrm{H}, d, J$ 
<smiles>[R20]c1ccc(-c2cc(=O)c3c(O)cc([R])cc3o2)cc1</smiles>

$1 R^{1}=R^{2}=H$

$2 \mathrm{R}^{1}=\mathrm{Me}, \mathrm{R}^{2}=\mathrm{H}$

$3 \quad R^{1}=H \quad R^{2}=\mathrm{OH}$

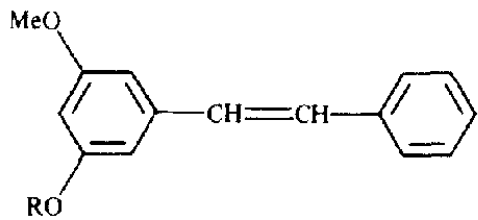<smiles>[R20]c1cc(O)c2c(c1)O[C@H](c1ccccc1)[C@@H]([R4])C2=O</smiles>

$4 R^{1}=R^{2}=H$

$5 \mathrm{R}^{1}=\mathrm{Me} \mathrm{R}^{2}=\mathrm{H}$

$6 \mathrm{R}^{1}=\mathrm{H}, \mathrm{R}^{2}=\mathrm{OH}$

$7 R^{1}=H \quad R^{2}=O A C$

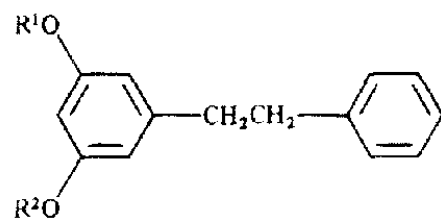

$11 R^{i}=R^{2}=H$

$12 \mathrm{R}^{1}=\mathrm{Me}, \mathrm{R}^{2}=\mathrm{H}$

$13 \mathrm{R}^{1}=\mathrm{R}^{2}=\mathrm{Me}$

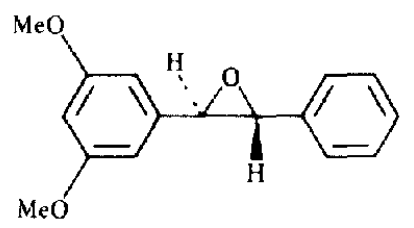

14

Table 1 Flavonoids in the heartwood of $P$ armand $\mathrm{Fr}$ var mavtersiana. $P$ morrisoncola Hay and $P$ pariffora Sieb et Zuce

\begin{tabular}{|c|c|c|c|}
\hline Compound & $P$ armandn & $P$ morrisonicola & $P$ parufitora \\
\hline Chrysn (1) & $*(951)$ & $*(5010)$ & * \\
\hline Tectochrysin (2) & $*(059)$ & $*(375)$ & \\
\hline Strobochrysin & & $*_{(0}(013)$ & \\
\hline Cryptochrysin & -- & $*(003)$ & \\
\hline Aplgenın (3) & $*\left(\begin{array}{lll}0 & 30\end{array}\right)$ & $*(010)$ & - \\
\hline Genkwann & & $*(0,13)$ & \\
\hline Gelangin & & $\left.*_{1}(0) 12\right)$ & \\
\hline Izalpının & - & $\left.*_{(0} \quad 18\right)$ & \\
\hline Pnocembrin (4) & $*(261)$ & $*(0 \leq 5)$ & * \\
\hline Pinostrobin (5) & $*\left(\begin{array}{ll}0 & 18\end{array}\right)$ & $*(026)$ & \\
\hline Pornel & - & $*(008)$ & \\
\hline Pinobanksin (6) & $*(285)$ & $*(313)$ & * \\
\hline Pinobanksin 3-acetate (7) & $*(356)$ & & \\
\hline 6-Methyl-punobanksin & & $*(0,46)$ & \\
\hline 6-Methyl-pmobanksin 3-acetate & & $*(0) 32)$ & \\
\hline Strobopinin & --- & & $*$ \\
\hline Cryptostrobın & & & * \\
\hline
\end{tabular}

*Indicates presence and - indicates absence of the spectfied flavonoid The number in parenthesis indicates relative percentage content 
Table 2. Stılbenes in the heartwood of $P$ armandti, $P$ morrisonicola. and $P$ parmflora

\begin{tabular}{|c|c|c|c|}
\hline Compound & $P$ armandu & $P$ morrisontcola & P. parviflora \\
\hline trans-Pinosylvin & - & $\left.*_{(0} 09\right)$ & * \\
\hline trans-Pinosylvin monomethyl ether (8) & $*(4280)$ & $*(3887)$ & * \\
\hline trans-Pinosylvin dimethyl ether (9) & $*(1420)$ & $*_{(022)}$ & -.. \\
\hline$c l s$-Pinosylvin & $*\left(\begin{array}{lll}0 & 12\end{array}\right)$ & $*(001)$ & - \\
\hline cis-Pınosylvin dimethyl ether (10) & $*(0.12)$ & $*\left(\begin{array}{lll}0 & 01\end{array}\right)$ & - \\
\hline Dihydropinosylvin (1.1) & $*\left(\begin{array}{lll}0 & 15\end{array}\right)$ & - & * \\
\hline Dihydropinosylvin monomethyl ether (12) & $*(1902)$ & $\ldots$ & * \\
\hline Dihydropinosylvin dimethyl ether (13) & $*(035)$ & $*(008)$ & - . \\
\hline trans-Pınosylvin oxıde dimethyl ether (14) & $*\left(\begin{array}{lll}0 & 12\end{array}\right)$ & $*\left(\begin{array}{lll}0 & 07\end{array}\right)$ & - \\
\hline
\end{tabular}

* Indicates presence and - indicates absence of the specified stilbene The number in parenthesis indiçates relatıve percentage content.

$=12 \mathrm{~Hz}, \mathrm{H}-2), 577(1 \mathrm{H}, d, J=12 \mathrm{~Hz}, \mathrm{H}-3), 597(1 \mathrm{H}, d, J$ $=2 \mathrm{~Hz}), 600(1 \mathrm{H}, d, J=2 \mathrm{~Hz}, \mathrm{H}-8), 742(5 \mathrm{H}, b r s)$

trans 3,5-Dimethoxystllbene oxide (14) Olly sample, $R, 053$ (4\% EtOAc-hexane), $[x]_{\mathrm{B}}^{25} 0^{5}\left(\mathrm{CHCl}_{3}, c 10\right) \mathrm{MS} m / z$ (rel. int.) $256\left[\mathrm{M}^{\prime}\right]$ (100), 255 (27), 241 (11), 239 (25), 238 (27), 227 (14), 225 (10), 208 (3), 165 (11), 91 (17) IR (neat) 1602, 1470, 1205, 1160, $1085 \mathrm{~cm}^{-1}{ }^{1} \mathrm{H}$ NMR $\left(\mathrm{CDCl}_{3}, 300 \mathrm{MHz}\right) \delta 378(6 \mathrm{H}, s), 381(2 \mathrm{H}$, $s), 641(1 \mathrm{H}, t, J=2 \mathrm{~Hz}), 649(1 \mathrm{H}, d, J=2 \mathrm{~Hz}), 734(5 \mathrm{H}, m)$

Acknowledgement-We thank the National Science Council (ROC) for financial support

\section{REFERENCES}

1 Anon (1975) Flora of Tawan Vol 1, pp 518-525 Epoch, Tawan

2 Fang, J M, Chang, C F and Cheng, Y S (1987) Phytochemistry 26, 2579

3 Hata, K and Sogo, M. (1954) J Jpn Forest Soc 36, 8

4 Erdtman, H, Kimland, B and Norın, T (1966) Phytochemistry 5,927
5 Baker, W, Hemming, R ann Ollıs, W D (1951) J Chem Soc. 691

6 Reed, R I and Wilson, J. M (1963) J Chem. Soc 5949

7 Suga, T, Iwata, N and Asakawa, Y (1972) Bull Chem Soc $J p n$ 45, 2058.

8. Bick, I R C, Brown, R B and Hills, W E (1972) Aust $J$ Chem 25, 449

9 Mongkolsuk, S and Dean, F M. (1964) J Chem. Soc 4654

10 Jeffers, P R., Knox, J R and Middleton, E. J (1962) Aust J Chem 15, 532

11 Umino, N, Ito, N and Ishida, R (1975) $J p n$ Kokal 75, 62; 977 Chem Abst. 83, $178825 z$.

12 Lindstedt, G (1951) Acta Chem Scand 5, 129

13 Lindstedt, G and Misiorny, A (1951) Acta Chem Scand. 5, 121

14. Bachelor, F W, Loman, A A and Snowdon, L R (1970) Can $J$ Chem 48, 1554

15 Rowe, J. W, Bower, C L and Wagner, E R (1969) Phytochemistry 8, 235

16 Chang, C F.(1986) M Se Thesss, Department of Chemistry, National Taıwan University 